\title{
Pathways for Reducing Anti-Nutritional Factors: Prospects for Vigna unguiculata
}

\author{
Abdou Diouf ${ }^{1,2,3^{*}}$, Fallou Sarr ${ }^{2,3}$, Birama Sene ${ }^{2,3}$, Cheikh Ndiaye ${ }^{2}$, Seynabou Momar Fall ${ }^{3}$ and \\ Nicolas Cyrille Ayessou ${ }^{1}$ \\ ${ }^{1}$ Laboratoire d'Electochimie et des Procédés Membranaires, Ecole Supérieure Polytechnique, Université Cheikh Anta DIOP de Dakar \\ BP 5085 Fann, Sénégal \\ ${ }^{2}$ Faculté des Sciences et Techniques, Université Cheikh Anta DIOP de Dakar BP 5005 Fann, Sénégal \\ ${ }^{3}$ Institut de Technologie Alimentaire (ITA) Route des pères Maristes, Hann-Dakar-Senegal - BP: 2765
}

Received: 07 March, 2019; Accepted: 8 April, 2019; Published: 27 May, 2019

*Corresponding author: Laboratoire d'Electochimie et des Procédés Membranaires, Ecole Supérieure Polytechnique, Université Cheikh Anta DIOP de Dakar BP 5085 Fann, Sénégal. Email: dioufabdou044@gmail.com

\begin{abstract}
Cereals, pulses and legumes are the most consumed foods in SubSaharan Africa. Cowpea, Vigna unguiculata (L.) walp is one known of these legumes as a good source of proteins, some minerals, and fibers. However, the presence of anti-nutritional factors (ANFs) including phytates, alpha - galactosides such as raffinose and stachyose, and tannins reduce significantly the micronutrients and also create some problems of acceptability in using cowpea and other legumes. This review article rep the current knowledges on key aspects of technologies used to reduce ANFs. Some of them proposed one either pathway or combining many techniques such as soaking, sprouting, fermentation, extrusion cooking and steam pre-cooking in order to reduce these ANFs. In fact, steam pre-cooking seems to be the most promising among established processes because of its potential to reduce ANFs up to $96 \%$. Nevertheless, soaking can reduce ANFs up to $45 \%$ with higher reductions by adding sodium bicarbonate. Sprouting however can record more significant reductions of 33 to $72 \%$ of tannins, $96 \%$ of phytates, $92 \%$ of stachyose and $67 \%$ of raffinose. With regard to fermentation, a reduction rate in ANFs exceeding $50 \%$ was found. The extrusion technic reduces up to $55.83 \%$ at $140{ }^{\circ} \mathrm{C}$ and $20 \%$ humidity while the steam pre - cooking resulted reductions of up to $52.60 \%$ at $110^{\circ} \mathrm{C}$ for 25 minutes. In this regard, it is critical to investigate mechanisms that would improve these reductions and furthermore, investigate all strategies used to increase bioavailability of nutrients under specific technological condition.
\end{abstract}

Keywords: Cowpea; anti nutritional factors; soaking; sprouting; fermentation; extrusions; steam pre - cooking

\section{Introduction}

Cereals and legumes are the most important consumed food based products in sub-Saharan Africa. Cowpea, Vigna unguiculata (L.) walp, is one well known legumes as an important source of protein for millions of people living in semi-arid countries [1]. It is a good legume for drought tolerance. Globally, West Africa has the largest production and consumption of cowpea including Senegal, where cowpea is the most widely grown legume seed after groundnuts $[1,2]$. Thus, the annual production of cowpea is 99924 tons and 117784 tons respectively in 2017 and 2018 [2, 3]. Nutritionally, mature cowpea seeds contain proteins, starch, vitamins B such as folic acid, which is important in preventing malformation in newborns [4]. In addition, cowpea proteins are highly digestible with important biological values [5]. Furthermore, cowpea seed contains 88.7g / 100g in Dry Matter (DM). This dry matter is composed by $1.2 \mathrm{~g} / 100 \mathrm{~g}$ in lipids, $24.3 \mathrm{~g}$ / $100 \mathrm{~g}$ in proteins, $31.0 \mathrm{~g} / 100 \mathrm{~g}$ in total fibers and 3.2g / 100g in ash, $50-67 \%$ starch $[4,6]$. Cowpea seed has also good amounts of iron and zinc respectively $8 \mathrm{mg}$ and $5 \mathrm{mg} / 100 \mathrm{mg}$ DM [7]. In addition, have shown that the consumption of one kilogram of cowpea seeds cover the daily energy allowance for an adult man, which is $3050 \mathrm{kcal}$ [8].

However, the presence of ANFs may negatively affect the acceptability of cowpea based food products, their proteins bioavailability, and minerals as well as in other legumes. According to, ANFs are found in almost all foods. However, several technological processes are used in order to reduce these ANFs and to provide consumers nutritional rich food products [9]. Moreover, these technological processes need to be optimized for more effectiveness. The purpose of this review paper covers the current and modern practices on key aspects of these technologies in reducing or eliminating ANFs in legumes. This state of art cross over above technologies could be also applied to Vigna unguiculata.

\section{Structure and Nutritional Effects of Some Major Antinutrients Factors (Anfs) in Legumes}

Plants have substances that can negatively impact digestion, nutrient uptake, and metabolism [10, 11]. These substances are mostly called antinutritional factors [12]. They reduce the absorption of micronutrients from plant based food products [13]. Thus, different ANFs are found in legume seeds and particularly in cowpea include phytates, tannins, andalpha-galactosides including raffinose, stachyose and verbascose $[14,15]$.

\section{Phytates}

Phytates are salts of phytic acids also called myo-inositolhexaphosphoric acid. With formula of C6H18024P6, this acid has 
an esterified inositol radical with six phosphate radicals Figure 1a. The amount of phytates in different legume samples differs from varieties ranging from 8.10 to $16.36 \mathrm{mg} / \mathrm{g}$ DM $[6,16]$. In cowpea seeds the phytate content can reach $836 \mathrm{mg} / 100 \mathrm{~g}$ and even further to $1230 \mathrm{mg} / \mathrm{g}$ DM $[17,18]$. The location of phytates in plants varies with the types. In legume seeds, they are stored in cotyledons [19]. Thus, in most seeds, phytates constitute the primary phosphate reserve having $60-90 \%$ of total phosphorus [20]. Phytates greatly influence functional and nutritional properties of food products by binding to minerals such as calcium, magnesium, copper, iron and zinc Figure 1b [21]. Thus will decrease their bioavailability. Phytates have a strong binding capacity and can therefore form complexes with proteins and multivalent cations that affect digestion. Indeed, studies have shown that most phytate metal complexes are insoluble at physiological pH rendering minerals not bioavailable [22]. However, all minerals haven't the same affinity for phytates and so there may be competition if the phytate / mineral balance is disrupted. Thus, the stability of phytates and their affinity for cations vary as follows: $\mathrm{Fe}<\mathrm{Ca}<\mathrm{Mn}<\mathrm{Co}<\mathrm{Cu}<\mathrm{Zn}$ [23]. The trace elements of nutritional interest are more strongly fixed by the phytic acid than the alkaline-earth macronutrients. However, because phytic acid is less digested by monogastric animals and by humans, and it interacts with amino acids and also chelates minerals such as $\mathrm{Fe}^{3+}, \mathrm{Zn}^{2+}$, and $\mathrm{Ca}^{2+}$, a high amount of phytic acid decreases the absorption of nutrients and their bioavailability. There are reported by that phytate molar ratio over zinc (Phy / $\mathrm{Zn)}$ greater than 10 or 15 progressively inhibited zinc uptake in rats fed diets of egg albumen supplemented with phytates or zinc [24]. They also reported that radioactive iron absorption in rats decreased significantly when phytate-to-iron molar ratios (Phy / Fe) were greater than 10-14 in wheat flour diets containing between 0.19 and $1.85 \mathrm{~g}$ phytates/100 g MS Figure 1.<smiles>O=P(O)(O)O[C@H]1[C@H](OP(=O)(O)O)[C@@H](OP(=O)(O)O)[C@H](OP(=O)(O)O)[C@@H](OP(=O)(O)O)[C@H]1OP(=O)(O)O</smiles>

a) Phytic acid

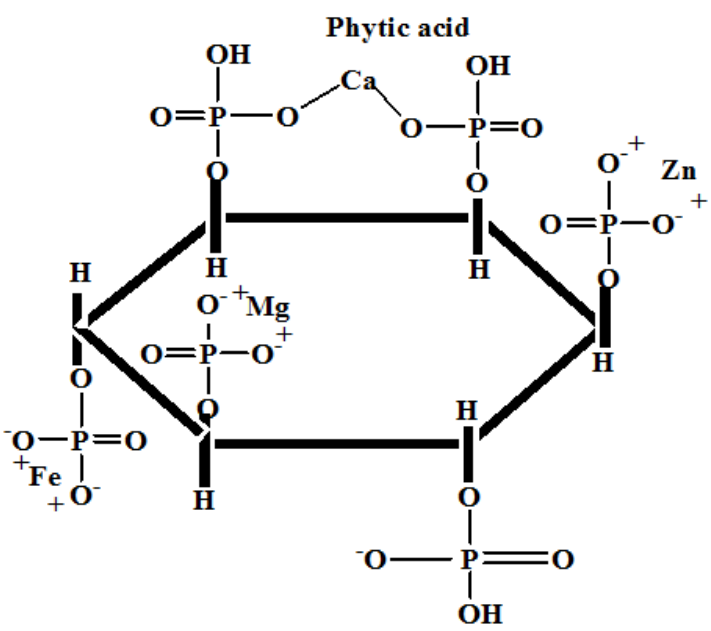

(b) phytate

Figure 1: Phytic acid and phytate structure [22, 25]

While other studies have shown that the phytate / iron molar ratio greater than 1 , indicates a low iron bioavailability and that the phytate / zinc molar ratio greater than 15 , is considered to be associated with reduced zinc absorption and a negative zinc balance [26]. Therefore, determination of phytate / mineral molar ratios would be interesting to measure the degree of inhibition of the latter by phytic acid and predict the availability of minerals in a food. Thus, these various results show that a high consumption of phytates can have harmful consequences on human health. Among these consequences, there are mineral deficiencies that most often affect women of childbearing age, children and people suffering from chronic blood loss. For example, in children and adolescents, iron deficiency is associated with decreased school performance [27].
To avoid these negative consequences of phytates, it is therefore important to put in place means to reduce their toxicity. To know the degree of toxicity or inhibition of phytates in a food, a determination of phytate / mineral molar ratios would be a good way.

\section{Alpha-Galactosides}

They are oligosides present in legumes seeds containing galactose whose osidic bonds are not hydrolysable by the digestive enzymes of human species $[28,29]$. They are unreducing, low molecular weight sugars, soluble in water and hydro alcoholic solutions [30]. The most common oligosides are raffinose and stachyose Figure 2 . Thus, the presence of alphagalactosides in foods appears to depend on species and genotype $[31,32]$. In cowpea seeds, the alpha-galactoside content varies 


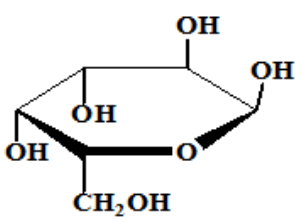

Galactose

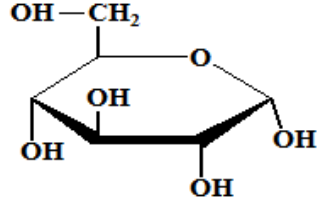

Glu cose

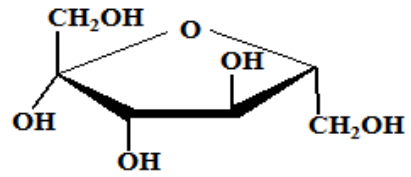

Fructose
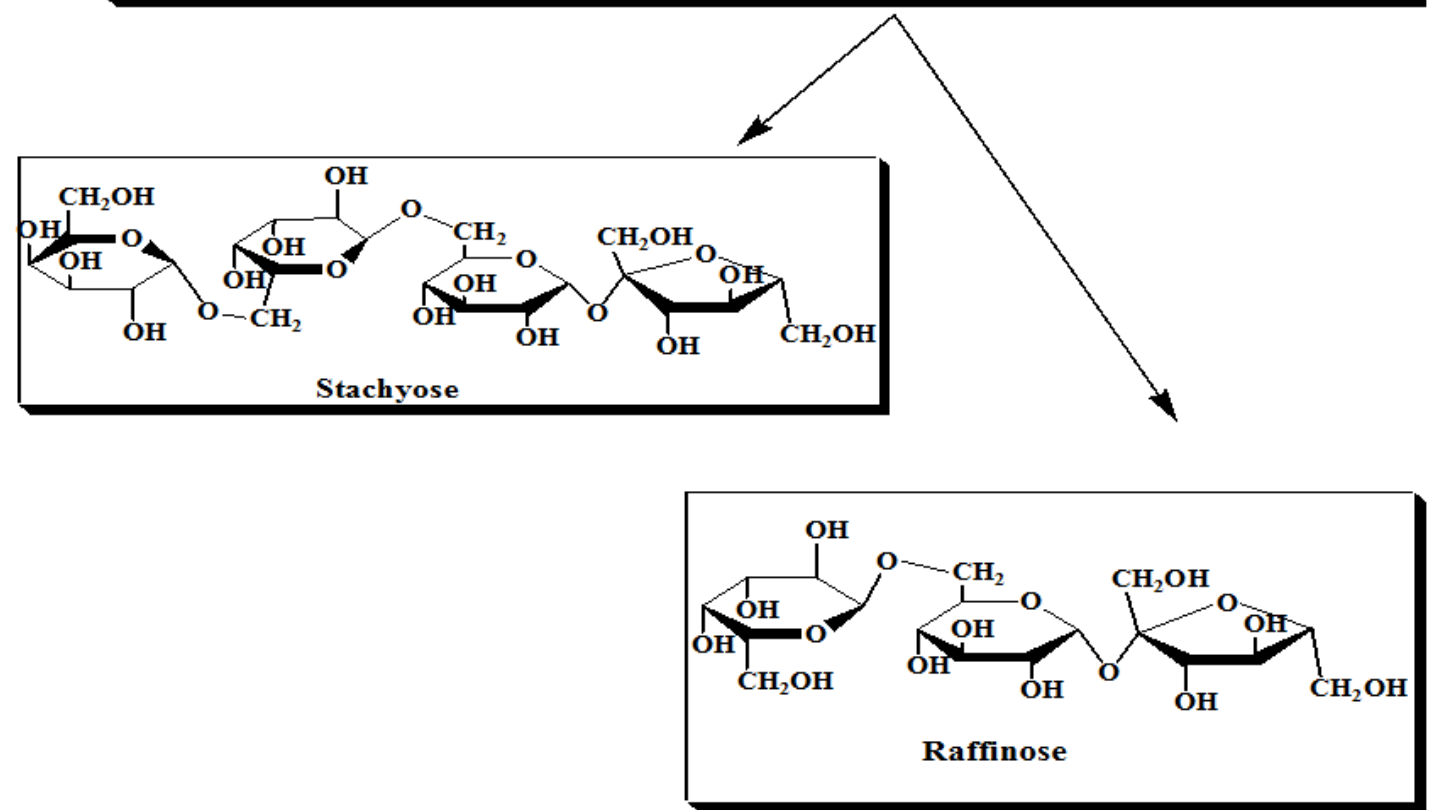

Figure 2: Chemical structure of raffinose and stachyose [30]

between 3.7 and 5.9\% [33]. In different pea varieties, the content alpha-galactoside found varies between 2.3 and 9.6\% [32, 34, 35]. However, lower levels of total alpha-galactosides (rafinose and stachyose) of $2.4 \%$ are found in lentil seeds [36].

These slightly differentlevels can be attributed to the difference in species between these two legumes. Alpha-galactosides are indigestible by the human body. They are not digested by humans because the intestinal mucosa is devoid of the hydrolytic enzyme $\alpha$-galactosidase and these sugars themselves are unable to cross the intestinal wall $[37,38]$. However, the microflora present in the large intestine is able to absorb them. Their absorption thus leads to the development of gases such as methane, hydrogen and carbon dioxide [38]. However, these gases are factors of flatulence for the human body. The major problem of alpha-galactosides is therefore their flatulence effect. The accumulation of flatulence in the intestinal tract causes discomfort, abdominal rumbling, cramps, pain and diarrhea. This phenomenon affecting certain individuals can be avoided if the levels are lowered. However, a thorough study is needed to determine threshold levels that can negatively affect the body.

\section{Tannins}

These are phenolic compounds of various structures that have the property of precipitating proteins. These are often polymerized compounds that give molecules of molecular weight ranging from 500 to $3000 \mathrm{Da}$ [39].

The tannins are subdivided into two categories according to their structure: hydrolysable and non-hydrolyzable tannins.

\section{Hydrolyzable Tannins}

These tannins, also called tannoids, belong to the family of glycosides. They are polyesters of carbohydrates and gallic acid and its derivatives such as digallic acid $[39,40]$.

\section{Condensed Tannins}

They are flavanolic polymers, consisting of flavan-3-ol units linked together by carbon-carbon bonds, most often C4-C8 or C4C6 Figure 3. Condensed tannins are often classified as flavonoids because of their similar structure. They do not contain sugars in their molecules and tend to polymerize by giving insoluble red 


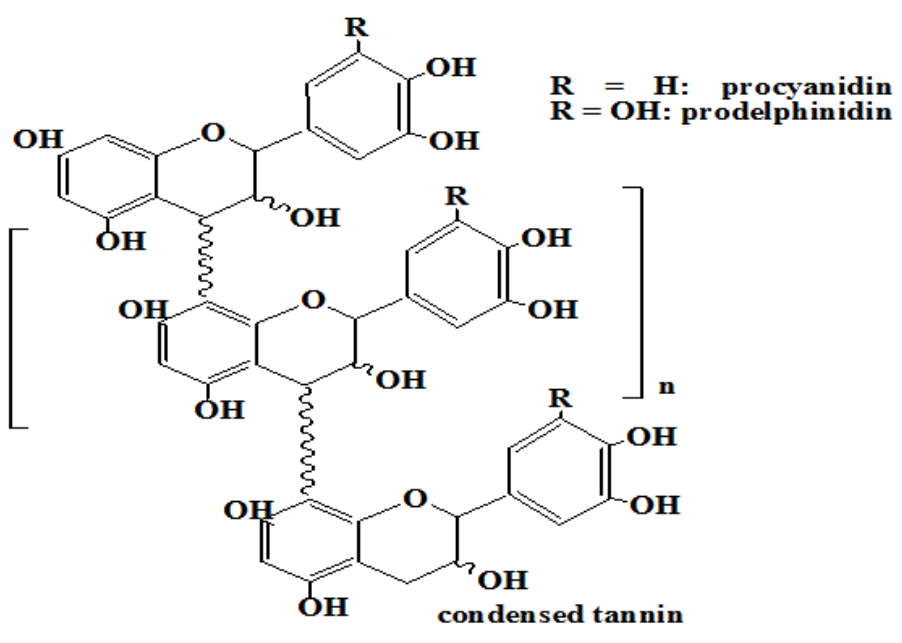

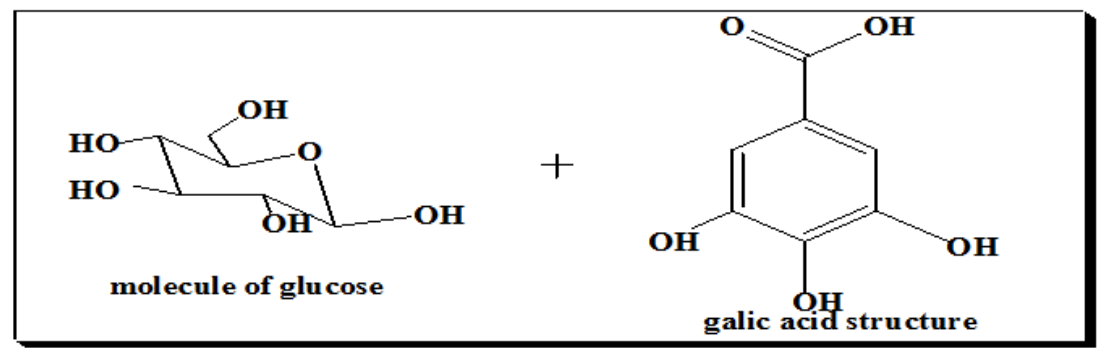

Figure 3: Structure of condensed and hydrolysed tannins [41, 42]

products $[39,41]$. It is these condensed tannins which are found in grains cereals and legumes.

Legume seeds are characterized by a condensed tannin content of 0.75 to $4.78 \%$ DM [6]. Condensed tannins can be used as antioxidant additives in fatty foods [43]. However, they have the disadvantage of binding to proteins, carbohydrates and minerals in seeds, reducing their nutritional value [44].

In cowpea, the tannin content can reach up to $260 \mathrm{mg} /$ $100 \mathrm{gMS}$ depending on the variety and color of the seeds [45]. This content is confirmed by the work of who found $270 \mathrm{mg} /$ $100 \mathrm{~g}, 680 \mathrm{mg} / 100 \mathrm{~g}, 110 \mathrm{mg} / 100 \mathrm{~g}$ and $820 \mathrm{mg} / 100 \mathrm{~g}$ tannins in 4 cowpea varieties respectively [14]. In view of these results, it is clear that tannins are significantly present in cowpea seeds. They can therefore prevent the availability of certain nutritional elements such as minerals and proteins, and this, thanks to their ability to form complexes with these elements thus blocking their absorption.

Antinutritional molecules therefore hinder efforts to combat malnutrition, micronutrient deficiency and food security. It is therefore necessary to propagate abatement techniques while avoiding too much nutrient loss.

\section{Processes for Reducing Anti nutritional Factors}

To improve the nutritional quality of cowpea seeds by limiting the negative effects of ANFs, different strategies can be adopted.

Indeed, there are several methods of treating seeds including soaking, germination, fermentation, extrusion, pre-cooking with steam, etc. 


\section{Soaking}

Traditionally, this operation was aimed at reducing the cooking time. This is an operation to hydrate the seeds by facilitating the diffusion and dissolution anti nutrients to the water phase. Soaking facilitates digestion and improves the absorption of contain nutrients by body [46]. The effect of soaking on ANFs content depends on its duration. Normal soaking requires an average of 8 to 12 hours at room temperature [16]. Table 1 gives some dipping processes carried out in different types of grains. A soak of 24 hours allows a significant reduction of its phytate content.

\begin{tabular}{|c|c|c|c|c|c|}
\hline Seeds Types & Soaking Solution Types & $\begin{array}{l}\text { Ratio (Weigh : } \\
\text { Volume) }\end{array}$ & $\begin{array}{l}\text { Soaking Times } \\
\text { / Soaking } \\
\text { Temperature }\end{array}$ & Reduction Rate & References \\
\hline Chick Pea & $\begin{array}{l}\text { Solution (water + 0,01N } \\
\mathrm{NaOH}+0,01 \mathrm{~N} \mathrm{HCl} \text { ) }\end{array}$ & $1: 5$ & -----/------ & -----/----- & $\begin{array}{l}\text { (Haileslassie and al., } \\
\text { 2016) [49] }\end{array}$ \\
\hline Beans & Tap water & $1: 5$ & 12 hours /---- & $\begin{array}{c}13.04 \%, 20.82 \% \text { for } \\
\text { tannins }\end{array}$ & $\begin{array}{c}\text { (Khandelwal and al., } \\
\text { 2010) [50] }\end{array}$ \\
\hline $\begin{array}{l}\text { Cereal Grains } \\
\text { (Millet, Sorghum } \\
\text { And Maize, Rice) }\end{array}$ & Mineral water (Evian) & $1: 3$ & 24 hours $/ 30^{\circ} \mathrm{C}$ & $28 \%$ of phytates & $\begin{array}{l}\text { (Lestienne and al., } \\
\text { 2005) [24] }\end{array}$ \\
\hline Bean & Distilled water & $1: 3$ & $----/----$ & ------/------ & $\begin{array}{c}\text { (Piecyk and al., 2012) } \\
{[51]}\end{array}$ \\
\hline Red Bean & $\begin{array}{c}\text { water }(\mathrm{pH}=6,9) 0,05 \% \\
\mathrm{Na}_{2} \mathrm{CO}_{3}, \mathrm{PH}=8,2 \text { solution }\end{array}$ & $1: 3$ & 12hours/ ambient & $\begin{array}{l}40,41 \text { and } 45 \% \text { of } \\
\text { alpha-galactoside }\end{array}$ & $\begin{array}{l}\text { (Shimelis and Rakshit, } \\
\text { 2007) [52] }\end{array}$ \\
\hline Cowpea & Mineral water (Evian) & $1: 5$ & 24 hours $/ 30^{\circ} \mathrm{C}$ & Increase $(-11.62 \%)$ & $\begin{array}{l}\text { (Lestienne and al., } \\
\text { 2005) [24] }\end{array}$ \\
\hline Cowpea & $\begin{array}{l}\text { Distilled water Solution of } \\
0,02 \% \mathrm{Na}_{2} \mathrm{CO}_{3} ; \mathrm{pH}=8,3 \text { ) }\end{array}$ & $1: 10$ & $\begin{array}{c}2,4 \text { et } 6 \\
\text { hours/----- }\end{array}$ & $\begin{array}{c}10.81 \%, 19.60 \% \\
\text { for phytates and } \\
22.22 \%, 32.92 \% \text { for } \\
\text { tannins }\end{array}$ & $\begin{array}{c}\text { (Avanza and al., 2013) } \\
{[14]}\end{array}$ \\
\hline
\end{tabular}

The reduction rates are $17 \%$ for rice grains, $21 \%$ for maize grains, $23 \%$ for soybeans and $28 \%$ for millet [24]. According to the results of a study on the evolution of anti nutritional factors of two cowpea seed varieties, soking in 24 hours resulted in a loss of $8.4 \%$ in phytates [47]. This loss of phytate levels has been confirmed or even exceeded by the studies of [48]. The latter obtained a reduction in the phytate content of 22.4 and $23.7 \%$ on two varieties of cowpea after 24 hours of soaking. The simple soaking of cowpea reduces the stachyose content by $30 \%$ [33]. These FAN reductions, which vary differently, can be attributed to their difference in water solubility. However, other dipping solutions are experimented such as the use of sodium bicarbonate.

Addition of sodium bicarbonate $\left(\mathrm{NaHCO}_{3}\right)$ to the soaking water can lead to significant reductions in ANF levels. Indeed, a 12 hours soaking with addition of sodium bicarbonate resulted in reductions of 41,45 and $40 \%$ in total alpha-galactoside (stachyose and raffinose) in three varieties of red beans respectively [52].

These results show that there is a difference in the contents of reduced ANFs according to the soaking solution used. The addition of sodium bicarbonate caused a greater reduction compared to soaking with simple water. Thus, the sharp reduction observed during the soaking with addition of sodium bicarbonate is due to the tenderness of the seeds facilitating the rapid dissolution of these factors in the soaking solution. These studies show that soaking is a good way to reduce ANFs in legumes such as cowpea. Thus, the loss of these ANFs during soaking of the seeds can be explained differently.

Regarding tannins, classified as polyphenols, are located at the level of the teguments and their loss during soaking of the seeds is attributed to its effect of creating an ionic environment $[14,53]$. The modified ionic environment could in turn modify the permeability of the integument, thus allowing larger and faster losses.

In addition, the decrease in phytic acid during this soaking process is attributed to its phytase catalyzed hydrolysis [14]. Thus this hydrolysis of the phytate molecule causes a release of minerals that become available for intestinal absorption.

However, it is important to note that during soaking, there is also a loss of certain nutritional elements such as minerals. It has shown by that cowpea seeds containing $6.60 \mathrm{mg} / 100 \mathrm{~g} \mathrm{DM}$ in iron are found with a content of $5.68 \mathrm{mg} / 100 \mathrm{~g}$ MS or 13.94\% loss after a $24 \mathrm{~h}$ soak [24]. According to, the minerals (potassium, 
calcium, magnesium and iron) whose losses have been observed in the seeds are found in the soaking water [33].

It is therefore important to recommend dipping food as a method of ANF control while controlling the duration of the operation to avoid large losses of minerals and water-soluble vitamins.

\section{Sprouting}

By definition, germination is a process that incorporates events beginning with the absorption of water by the mature dry seed and ending with the protrusion of the radicle or more generally of a portion of the embryo through the envelopes of the seed [54].

Germination is often used to improve the concentration and bioavailability of nutrients in foods $[55,56,57]$.
It improves the nutritional value of cereals and legumes by increasing protein digestibility, essential amino acid content and vitamins, while decreasing some anti nutritional factors [58]. Thus, during germination, important changes occur between the seeds and the culture medium. Changes include among others to the secretion of ions, oxygen and enzymes and a wide range of primary and secondary carbon-containing metabolites [59].

Germination can cause phytate hydrolysis and decrease their inhibitory effects on mineral uptake. It lasts a few days and can be initiated by a few simple steps namely rinsing the seeds to remove all the impurities, soaking the seeds in the water. Table 2 gives a summary of the conditions used for germination for different types of cereals and pulses. Germination results in 37 to $81 \%$ reduction of phytate in different types of cereals and legumes [60].

Table 2: Conditions used for germination of different types of kernels

\begin{tabular}{|c|c|c|c|c|c|}
\hline Seeds Types & $\begin{array}{l}\text { Ratio Seed : Soaking } \\
\text { Solution(W/V) }\end{array}$ & $\begin{array}{c}\text { Times /Temperatures/ } \\
\text { Nature Of Soaking Solutions }\end{array}$ & $\begin{array}{l}\text { Duration of } \\
\text { Germination }\end{array}$ & Reduction Rate & References \\
\hline $\begin{array}{l}\text { Millet, } \\
\text { Sorghum }\end{array}$ & ----- & 24 hours $/ 25^{\circ} \mathrm{C} /-----$ & 7 days & ----- & $\begin{array}{l}\text { (Ochanda and } \\
\text { al., 2010) [61] }\end{array}$ \\
\hline Amaranth & ---- & $\begin{array}{l}\text { Night/----/ Distilled water }+ \\
0,2 \% \text { formaldehyde solution }\end{array}$ & 72 hours & $34,66 \%$ of tannins & $\begin{array}{l}\text { (Olawoye and } \\
\text { Gbadamosi, } \\
\text { 2017) [62] }\end{array}$ \\
\hline $\begin{array}{l}\text { Beans (Green } \\
\text { Beans / Mung } \\
\text { Beans) }\end{array}$ & $1: 5$ & 12hours/ambiente/ Tap water & 24 hours & $43 \%$ of tannins & $\begin{array}{l}\text { (Khandelwal } \\
\text { and al., 2010) } \\
{[50]}\end{array}$ \\
\hline Red Beans & $1: 5$ & $\begin{array}{c}12 \text { hours } / 25^{\circ} \mathrm{C} / \quad \text { Distilled } \\
\text { water }+0.01 \%(\mathrm{w} / \mathrm{v}) \mathrm{d}^{\prime} \text { 'eau de } \\
\text { javel }\end{array}$ & 4 days & $\begin{array}{l}76 \% \text { of tannin } \\
92 \% \text { of phytic } \\
\text { acid }\end{array}$ & $\begin{array}{c}\text { (Shimelis and } \\
\text { Rakshit, 2007) } \\
\text { [52] }\end{array}$ \\
\hline
\end{tabular}

The 4-day sprouting of three bean varieties resulted in a gradual reduction of phytic acid levels from 23.51 to 1.88 , from 24.06 to 5.06 and from 17.34 to $0.69 \mathrm{mg} / \mathrm{g}$ are losses of $92.00 \%$, $79.76 \%$ and $96.02 \%$ respectively [52]. This technique is an effective method to reduce phytate levels, but its effectiveness is variable depending on the germinated material, the germination conditions and especially the germination time.

Moreover, the efficiency of the germination is maximum if the amount of enzymes capable to hydrolyze phytates is high and if the germination conditions are favorable to the activity of its enzymes. Germination also causes large reductions in phenolic compound contents ranging from 9 to $56 \%$ and particularly in tannins from 33 to $72 \%$ [6].

In a study of the evolution of anti nutritional factors of two varieties of cowpea seed, "voanembafotsy" and "voanemba mena", it was found that after 48 to 96 hours of germination, the phytate content cowpea is reduced by 48.8 and $81.8 \%$ respectively [47].
According to, after 96 hours of germination, the phytate content of the mara variety decreased by $41.5 \%$ under laboratory conditions [48]. Other studies have shown that the raffinose content decreases steadily with increasing germination time.

For a period of 5 days of germination, the raffinose content decreased steadily by $67 \%$ [63]. While found raffinose reductions of 38 and $62 \%$ for $24 \mathrm{~h}$ and $48 \mathrm{~h}$ germination respectively [52]. For the same germination times, the stachyose content was reduced by 53 and $92 \%$, respectively [52]. This decrease in phytates and alpha-galactoside is due to the presence of specific enzymes, phytase and alpha-galactosidases. In fact, the different phytases present in the seeds act during seed germination [64]. A study comparing the effect of pressure cooking, dipping and of germination showed that the greatest reduction in polyphenol and tannin content was achieved by germination, followed by dipping and pressure cooking [50]. The different results observed during germination confirm its effectiveness in reducing FANs. Thus, germination times varying between 48 and $72 \mathrm{~h}$ would be sufficient to significantly reduce the FAN content in legume seeds. 


\section{Fermentation}

Fermentation is one of the effective, inexpensive and nutritionally beneficial domestic processes [65]. Fermentation not only improves food safety and shelf life, naturally preserving food and also improves nutritional value [61].

This is a treatment technique that starts with the hydrolysis of starch by the action of enzymes. In general, lactic acid bacteria are essential in fermentations for the production of metabolites, degradation of cyanogenic glucosides, production of enzymes, probiotic properties and the production of many other molecules [66]. The reduction of FAN levels during fermentation is attributed to the activity of fermentative microorganisms [67]. Fermentation leads to a decrease in alpha - galactosides and phytates and has a positive effect on the availability of iron and other minerals $[68,69]$. It promotes optimal $\mathrm{pH}$ for the enzymatic degradation of phytates [69].

It reduces the levels of some anti nutritional factors, particularly phytates and $\alpha$-galactosides, in cereals and legumes, for millet, it reduces phytate and raffinose content by $75 \%$ and $83 \%$ respectively $[70,71]$. Fermentation is therefore a microbial and enzymatic method of treatment which not only extends the shelf life of foods but leads to a significant reduction in FAN levels. This reduction role is indeed made possible by the lowering of the $\mathrm{pH}$. Compared with soaking, the reduction rate obtained by fermentation is more significant; this leads to the conclusion that the use of fermentation for the treatment of seeds legumes and particularly cowpea would be a good asset of the nutritional point.

\section{Extrusion Cooking}

Extruders whose use for food processing for the first time dates back to 1869 and has led to a widespread development of extrusion cooking [70]. The extrusion cooking technique is a process that combines thermal and mechanical processes to produce a precooked product. This technique reduces ANFs by increasing the bioavailability of minerals [72]. It thus makes it possible to reduce phytates by approximately $30 \%$ [73]. It was found by reductions in phytic acid of $26.73 \%$ and $20.75 \%$ in extruded seeds of beans (Vicia faba L.) and green beans (Phaseolus vulgaris) respectively[74]. Studies have shown that during the extrusion cooking process some phytic acid molecules are hydrolysed to inositol penta-, tetra- and triphosphates [74].

However, the extrusion temperature and the moisture of the product to be extruded play an important role in the reduction of ANFs. Thus, a 55.83\% reduction in phytic acid was observed during extrusion cooking of rice bran at a temperature of 140 ${ }^{\circ} \mathrm{C}$ and 20\% humidity [75]. A lower moisture content during extrusion results in a lower degradation of the phytic acid of grain brans. According to at $115{ }^{\circ} \mathrm{C}$ the average values of phytic acid in extruded rice brans were 19.92, 18.63 and $17.35 \mathrm{mg} / \mathrm{g}$ at 14,17 and $20 \%$ humidity respectively [75]. The observation of these results makes it possible to remember that the extrusion temperature is a factor that can significantly influence the ANFs content compared to the moisture of the extruded product. Thus, $140^{\circ} \mathrm{C}$ temperature and $20 \%$ humidity would be the most appropriate parameter pair for reducing ANFs in a food product. In addition, the technique of extrusion cooking compared to the other processes studied above would be preferable. Indeed, it makes available minerals without destroying them while other processes such as soaking and germination cause a diffusion of these minerals in the soaking water.

\section{Steam Pre-Cooking}

Steam pre - cooking is a unit operation used for the processing of certain food products, in this case rice and millet. It is applied to enhance the nutritional quality of rice [76]. Studies have shown that this process reduces FAN levels in legume and cereal seeds.

In fact, steam pre - cooking resulted in a $52 \%$ reduction in phytate content of beans, $56.5 \%$ in sunflower and $47.9 \%$ in rice grains [77]. In the production of "moin-moin" (steamed cowpea paste containing seasonings), there was a decrease in phytate contents between $7.8-14.0 \%$ and tannins of 19.6-24. 7\% [78]. This decrease in phytate during heat treatment would be the result of their degradation by heat. This is due to the thermolabile nature of phytic acid [79].

For tannins, they are localized at the level of grain teguments and are destroyed during the heat treatment process [80]. In this thermal process, the temperature and the treatment time are good optimization parameters. Reductions in average phytic acid content from $38.14 \mathrm{mg} / \mathrm{g}$ for untreated cereal brans at $18.72 \mathrm{mg}$ / g for cereal brans subjected to steam pre-cooking at $100^{\circ} \mathrm{C}$ for 25 minutes, $18.08 \mathrm{mg} / \mathrm{g}$ at $110^{\circ} \mathrm{C}$ for 25 minutes and $18.74 \mathrm{mg} /$ $\mathrm{g}$ at $115^{\circ} \mathrm{C}$ for 25 minutes were recorded [81]. These recordings showed that the maximum reduction $(52.60 \%)$ of the phytic acid content was obtained at $110^{\circ} \mathrm{C}$ for 25 minutes.

Thus, in the case of cowpea, similar losses in ANFs could be considered because of the heat labile nature of some of them or their location in teguments whose heat facilitates their destruction. A combination of this treatment technique with the other processes could give better reductions in ANFs while retaining nutritional and organoleptic qualities of the final product.

\section{Conclusion}

This literature review has revealed that there are various methods of reducing anti nutritional factors. Reduction techniques such as soaking, germination, fermentation, extrusion cooking and steam pre-cooking have been found to be often used methods. Thus, the study showed that a significant reduction in ANFs greater than $50 \%$ is obtained by germination, fermentation, extrusion cooking and pre - cooking with steam. However, the steaming technique is rarely used, especially in the case of cowpea. This allows us to think that the combination of this process with other techniques could be a good track for reducing ANFs in food and especially cowpea. 


\section{References}

1. FAO. (Food and Agriculture Organization of the United Nations), Statistical Database. 2014.

2. ANSD. National Agency of Statistics and Demography). Monthly Bulletin of Economic Statistics. Dakar. 2017.

3. ANSD. (National Agency of Statistics and Demography). Monthly Bulletin of Economic Statistics. Dakar. 2018; 109 p.

4. Cisse, N., Hall, A., 2001. Traditional cowpea culture in Senegal, case study. ISRA / CNRA BP 53, 92521-90124.

5. Rangel A, Saraiva K, Schwengber P, Narciso MS, Domont GB, Ferreira ST, et al. Biological evaluation of a protein isolate from cowpea (Vigna unguiculata). Food Chemistry 87. 2004; 491-499.

6. Lestienne, I., 2004. Contribution to the study of the bioavailability of iron and zinc in millet grain and conditions for improvement in complementary foods. Montpellier: University Montpellier II.

7. Amjad Iqbal, Iqtidar A. Khalil, Nadia Ateeq, Muhammad Sayyar Khan. Nutritional quality of important food vegetables. Food chemistry.2005; 97(2006): 331-335. doi:10.1016/j.foodchem.2005.05.011

8. Denise, BMA, Salome, YSE, Clovis, KNdB, et al. Agronomic and Biochemical Quality Study Some Cowpea Varieties (Vigna Unguiculata (L) Walp (Fabaceae).Ivory Coast European Scientific Journal.2016;

9. Aukwa, C. A.; Igwenyi, I. O.; Ogah, O.; Oor, C. E.; Ugwu, O. O. Variations in seed phytic and oxalic acid contents among Nigerian cowpea accessions and their relationship with grain yield. Continental Journal of Food Science and Technology.2011; 5(2):40-48.

10. KO Soetan. Pharmacological and other beneficial effects of antinutritional factors in plants. African Journal of Biotechnology 2008; 7 (25): 4713-4721.

11. Ross M. Welch and Robin D. Graham. 2004. Breeding for micronutrients in staple wheat and wheat fractions. Cereal Chemistry 47; 2004: 288296.

12. Burel, C., Médale, F., 2014. What about the use of plant-based proteins in aquaculture? OCL 21, D406.

13. Habtamu Fekadu Gemede and Negussie Ratta. Antinutritional factors in plant foods: potential health benefits and adverse effects. Internationa Journal of Nutrition and Food Sciences.2014;3(4):284-289.

14. M.Avanza, B.Acevedo, M.Chaves, M.Añón. Nutritional and antinutritional components of four cowpea varieties under thermal treatments: Principal component analysis. LWT-Food Science and Technology. 2013;51(1):148-157.Doi:10.1016/j.lwt.2012.09.010

15. Bolade MK. Individualistic impact of unit operations of production, at household level, on some antinutritional factors in selected cowpeabased food products. Food Sci Nutr. 2015;4(3):441-55

Doi: $10.1002 /$ fsn 3.306

16. Andrianirina J. Nutritional and anti-nutritional characterization of legume seeds consumed in Androy. (DEA thesis in Biochemistry Applied to Food Science and Nutrition). Faculty of Science: Antananarivo University.2015.

17. R. Sinha and A. Kawatra. Effect of processing on phytic acid and polyphenol contents of cowpeas [Vigna unguiculata (L) Walp]. Plant Foods for Human Nutrition. 2003;58(3):1-8

18. Iyayi, E. A., Kluth, H., Rodehutscord, M. Effect of heat treatment on antinutrients and precaecal crude protein digestibility in broilers of four tropical crop seeds. International journal of food science \& technology. 2008;43(4):610-616.
19. Magnolia Ariza-Nieto, Matthew W. Blair, Ross M. Welch, Raymond P. Glahn. Screening of iron bioavailability patterns in eight bean (Phaseolus vulgaris L.) genotypes using the Caco-2 cell in vitro model. J. Agric. Food Chem. 2007;55(19):7950-7956. DOI: 10.1021/ jf070023y

20. Santosh Khokhar and Richard K. Owusu Apenten. Antinutritional factors in food vegetables and effects of processing. The role of food, agriculture, forestry and fisheries in human nutrition.2004;

21. B Feil. Phytic acid. Journal of New Seeds.2001; 3(3):1-35.Doi:10.1300/ J153v03n03_01

22. J. Mellef, A. Dridi, L. El bahri, O. Belhaj. Review of the effects of the addition of microbial phytase on the bioavailability of phosphorus and the performance of poultry. Revue de Médecine Veterinaire.2010; 161(7): 342-352

23.J. W. Erdman. Oilseed phytates: nutritional implications. Journal of the American Oil Chemists' Society.1979; 56(8):736-741.Doi. org/10.1007/BF02663052

24. Isabelle Lestienne, Christèle Icard-Vernière, Claire Mouquet, Christian Picq, Serge Trèche. Effects of soaking whole grain and legume seeds on iron, zinc and phytate contents. Food Chemistry.2005;89(3):421-425. Doi:10.1016/j.foodchem.2004.03.040

25. Maduabuchi A. Chidiebere, Simeon, Nwanonenyi, Demian Njoku, Nkem B. Iroha, Emeka E. Oguzie, Ying Li. Experimental study on the inhibitive effect of phytic acid as a corrosion inhibitor for Q235 mild steel in $1 \mathrm{M} \mathrm{HCl}$ environment. World News of Natural Sciences. 2017;15(2017):1-19.

26. Sonia Tamanna, Sayma Parvin, Sanjay Kumar, Alak K Dutta, Aysha Ferdoushi, M Ali Siddiquee, et al. Content of some minerals and their bioavailability in selected popular rice varieties from Bangladesh. Int.J.Curr.Microbiol.App.Sci.2013;2(7): 35-43.

27. Halterman JS, Kaczorowski JM, Aligne CA, Auinger P, Szilagyi PG. Iron deficiency and cognitive achievement among school-aged children and adolescents in the United States. Pediatrics.2001;107(6):1381-1386.

28. S. Trèche. Complementary feeding of young children: proceedings of a WHO-ORSTOM inter-country workshop, from 20 to 24 November 1994, at Senghor University, Alexandria. Egypt. IRD Editions.1995.

29. In Hwa Han and Byung-Kee Baik. Oligosaccharide content and composition of vegetables and their reduction by soaking, cooking, ultrasound, and high hydrostatic pressure. Cereal Chemistry.2006;83(4): 428-433.Doi: 10.1094/CC-83-0428

30. Cristina Martínez-Villaluenga Juana Frias, Concepción Vidal-Valverde, Alpha-Galactosides: Antinutritional Factors or Functional Ingredients? Critical reviews in Food Science and Nutrition.2008;48(4):301-316.

31. Prakash M.Dey. Biochemistry of $\alpha$-D-galactosidic linkages. Advances in Carbohydrate Chemistry and Biochemistry.1980; 37:283-372. DOI: 10.1016/S0065-2318(08)60023-2

32. N.R.Reddy, M.D.Pierson, S.K.Sathe, D.K.Salunkhe. Chemical, nutritional and physiological aspects of dry carbohydrate beans-A review. Food Chem.1984;13(1):25-68.Doi:10.1016/0308-8146(84)90026-8

33. F.B Souilah. Characterization of the behavior of micronutrients of interest and antinutritional compounds of chickpeas and cowpeas during processing processes, Montpellier Sup Agro, Institute of Hot Regions. University of Montpellier, University of Montpellier.2015. 
34. Troszynska, A., Honke, J., Waszczuk, K., and Kozlowska, H. Oligosaccharide content in vegetables and their changes during sterilization. In: Improving production and utilization of Grain. pp. 288. AEP (ed.), Proceedings of the 2nd European Conference on Grain Legumes, AEP, Paris.1995.

35. Concepción Vidal-Valverde, Juana Frias, Amelia Hernández, Pedro J Martín-Alvarez, Isabel Sierra, Carmen Rodríguez, et al. Assessment of nutritional compounds and antinutritional factors in pea seeds (Pisum sativum). J. Sci. Food Agric.2003;83(4): 298-306. Doi: 10.1002/ jsfa.1309

36. Kozlowska, H ., Pilar, A., Dostalova, J., Frias, J., Lopez-Jurando, M., Pokorny, J., Urbano, G., Vidal-Valverde, C. and Zdunczyk, Z. Nutrition, In: Carbohydrate in Grain Legumes Seeds, Hedley C.L. (Ed.).2001.6187, CAB International

37. E Cristofaro, F Mottu, J.J Wuhrmann. Involvement of the family raffinose of oligosaccharides in flatulence. In: Sugars in Nutrition. Sipple, H. L., McNutt, K.W., Eds., London, Academic Press.1974;313-336.

38. Yadahally N.Sreerama, adakkoot B.Sashikala, Vishwas M.Pratape, Vasudeva Singh. Nutrients and antinutrients in cowpea and horse gram flours in comparison to chickpea flour: Evaluation of their flour functionality. Food chemistry.2012; 131(2):462-468. Doi: 10.1016/j. foodchem.2011.09.008

39. E. Bassène. Introduction to Research on Natural Substances ExtractionAnalyzes-Biological Tests. Dakar University Press.2012.

40. B.R Min, T.N Barry, G.T Attwood, W.C McNabb. The effect of condensed tannins on the nutrition and health of ruminants fed fresh temperate forages: a review. Animal Feed Science and Technology.2003;106(1-4): 3-19.Doi:10.1016/S0377-8401(03)00041-5

41. N. Zimmer and R. Cordesse. Influence of tannins on the nutritional value of ruminant feeds. INRA Prod. Anim.1996;9 (3):167-179.

42. Raymond V.Barbehenn and C.Peter Constabel. Tannins in plantherbivore interactions. Phytochemistry.2011;72(13):1551-1565. Doi:10.1016/j.phytochem.2011.01.040

43. F.E. Sikwese and K.G. Duodu. Antioxidant effect of crude phenolic extract from sorghum bran in sunflower oil in the presence of ferric ions. Food Chemistry.2007;104(1): 324- 331. Doi:10.1016/j. foodchem.2006.11.042

44. K. Ba, E. Tine, J. Destain, N. Cisse, P. Thonart. Comparative study of phenolic compounds, the antioxidant power of different varieties of Senegalese sorghum and the amylolytic enzymes of their malt. Biotechnol. Agron. Soc. Environ. 2010;14(1):131-139.

45. E. Marconi, G. Lombardi-Boccia, E. Carnovale. Nutritional evaluation of wild and cultivated species of cowpea. Cowpea genetic resources.1990;101-110.

46. Ana Carolina Fernandes, Waleska Nishida, Rossana P. da Costa Proenca. Influence of soaking on the nutritional quality of common beans(Phaseolus vulgaris L.) cooked with or without the soaking water: a review. International Journal of Food Science \& Technology.2010;45: 2209-2218.

47. Z. J Andriantsoa. Evolution of antinutritional factors of two varieties of cowpea (vignaunguiculata), voanemba mena and voanemba fotsy, during germination. (DEA dissertation of Biochemistry applied to the sciences of food and nutrition). Faculty of Science: Antananarivo University.2006.

48. N. Razafitsalama. Evolution of antinutritional factors of seeds of two varieties of voandzou, mara and fotsy, during germination. DEA dissertation of Biochemistry applied to the sciences of food and nutrition). Faculty of Science: University of Antananarivo. 2006.

49. Hiwot A. Haileslassie, Carol J. Henry, Robert T. Tyler. Impact of household food processing strategies on antinutrient (phytate, tannin, and polyphenol) contents of chickpeas (Cicer arietinum L.) and beans (Phaseolus vulgaris L.): a review. International Journal of Food Science \& Technology.2016; 51(9):1947-1957. Doi:10.1111/ijfs.13166

50. Shweta Khandelwal, A. Udipi Shobha, Padmini Ghugre. Polyphenols and tannins in Indian pulses: Effect of soaking, germination and pressure cooking. Food Research International. 2013;43(2):526-530.

51. Małgorzatapiecyk, Rafałwołosiak, Beatadrużynska, Elwiraworobiej. Chemical composition and starch digestibility in flours from Polish processed legume seeds. Food Chemistry.2012;135(3):1057-1064. Doi: 10.1016/j.foodchem.2012.05.051

52. Emire AdmassuShimelis and Sudip KumarRakshit. Effect of processing on antinutrients and in vitro protein digestibility of kidney bean (Phaseolus vulgaris L.) varieties grown in East Africa. Food chemistry.2007;103(1): 161-172. Doi: 10.1016/j. foodchem.2006.08.005

53. Magnolia Ariza-Nieto, Matthew W. Blair, Ross M. Welch, Raymond P. Glahn. Screening of iron bioavailability patterns in eight bean (Phaseolus vulgaris L.) genotypes using the Caco-2 cell in vitro model. J. Agric. Food Chem. 2007;55(19):7950-7956. DOI: 10.1021/ jf070023y

54. Loïc Rajjou, Manuel Duval, Karine Gallardo, Julie Catusse, Julia Bally, Claudette Job, et al. Seed germination and vigor. Annual review of plant biology.2012; 63:507-533. Doi:10.1146/annurevarplant-042811-105550

55. Samia M. Abdelrahaman, Hagir B. Elmaki, Wisal H. Idris, Amro B. Hassan, Elfadil E. Babiker. Antinutritional factors et aqueouschloride acid extractabilité des minerals en pearl millet cultivars as affected by germination. Int. J. Food Sci. Nutr.2007;58(1):6-17. Doi:10.1080/09637480601093236

56. Mashair A. Sulieman, Mashair A. Sulieman, Mohamed M. Eltayeb, Elfadil E. Babiker, Abdelmoneim I. Mustafa, Abullahi H. El Tinay. Effect of sprouting on chemical composition and amino acid content of Sudanese lentil cultivars. J. Appl. Sci.2008;8(12):23372340.Doi: 10.3923 /jas.2008.2337.2340

57. Awad M. Sokrab, Isam A. Mohamed Ahmed, Elfadil E. Babiker. Effect of malting and fermentation on antinutrients, and total and extractable minerals of high and low phytate corn genotypes. Int. J. Food Sci. Techol.2012;47(5):1037-1043. Doi:10.1111/j.13652621.2012.02938.x 
58. Mandeep S Sibian, Dharmesh C Saxena, Charanjit S Riar. Effect of germination on chemical, functional and nutritional characteristics of wheat, brown rice and triticale: a comparative study. Journal of the Science of Food and Agriculture.2017;97(13):4643-4651. Doi:10.1002/jsfa.8336

59. Bais HP, Weir TL, Perry LG, Gilroy S, Vivanco JM.The role of root exudates in rhizosphere interactions with plants and other organisms. Annu Rev Plant Biol. 2006;57:233-266

60. Luo Y, Xie W, Luo F.Effect of several germination treatments on phosphatases activities and degradation of phytate in faba bean (Vicia faba L.) and azuki bean (Vigna angularis L.). J Food Sci. 2012;77(10):C1023-C1029. Doi: 10.1111/j.17503841.2012.02733.x

61. Ochanda, Simon Oduor, Onyango Christine Akoth, Mwanjala Alfred Mwasaru, Ochieng Joy Kagwiria, Mathooko Francis Mutiso.Effects of malting and fermentation treatments on group B-vitamins of red sorghum, white sorghum and pearl millets in Kenya. J. Appl. Biosci.2010;34:2128-2134.

62. Babatunde Olawoye and Saka Olasunkanmi Gbadamosi.Effect of different treatments in vitro protein digestibility, antinutrients, antioxidant properties and mineral composition of Amaranthus viridis seed. Cogent Food \& Agriculture.2017;3(1): 1296402. DOI: $10.1080 / 23311932.2017 .1296402$

63. I Onyesom, AT Enaholo, J Mordi. Effect of processing techniques on the contents of flatulence factors and emulsion properties of cowpea (Vigna unguiculata). Journal of Applied Sciences and Environmental Management. 2005; 9(2):65-72. Doi:10.4314/jasem.v9i2.17293

64. Frank Hatzack, Frank Hübel, Wei Zhang, Poul E. Hansen, Søren K. Rasmussen.Inositol phosphates from barley low-phytate grain mutants analysed by metal-dye detection HPLC and NMR. Biochemical Journal.2001;354(2): 473-480.Doi: 10.1042/bj3540473

65. K. Y. Mehas and S. L. Rodgers. Fermentation and food. Food Science and You.1989. Macmillan/McGraw-Hill.

66.Z. Kohajdová and J.Karovičová. Fermentation of cereals for specific purpose. Journal of Food and Nutrition Research.2007;46(2):51-57.

67. T.N. Fagbemi and H.N. Atum. Physicochemical changes and microorganisms involved in the natural fermentation of Hura crepitans seeds to produce ogiri. Appl. Too much. Agric.2001;6:51-56.

68. Marisela Granito, Juana Frias, Rosa Doblado, Marisa Guerra, Martine Champ, Concepción Vidal-Valverde. Nutritional improvement of beans (Phaseolus vulgaris) by natural fermentation. European Food Research and Technology.2002;214(3):226-231. Doi:10.1007/ s00217-001-0450-5

69. VikasKumar, Amit K.Sinha, Harinder P.S.Makkar, KlausBecker. Dietary roles of phytate and phytase in human nutrition: A review. Food Chemistry.2010;120(4):945-959. Doi:10.1016/j. foodchem.2009.11.052
70. M.B. Dominique, M.G.J.F.A. Ouest, R.M.T. Serge, I. Madagascar. Conditions of use of a "very low cost cooker-extruder" for the manufacture of infant flours in Vietnam.2008;

71. E.H.Tou, J.P.Guyot, C.Mouquet-Rivier, I.Rochette, E.Counil, A.S.Traoré, et al. Study through surveys and fermentation kinetics of the traditional processing of pearl millet (Pennisetum glaucum) into ben-saalga, a fermented gruel from Burkina Faso.International Journal of Food Microbiology.2006;106(1):52-60. Doi:10.1016/j. ijfoodmicro.2005.05.010

72. A.A. Adebowale, S.T. Kareem, O.P. Sobukola, M.A. Adebisi, A.O. Obadina, O.E. Kajihausa, et al. Mineral and Antinutrient Content of High Quality Cassava-Tigernut Composite Flour Extruded Snack. Journal of Food Processing and Preservation.2017;41(5): e13125.Doi:10.1111/ jfpp.13125

73. Amagloh FK, Hardacre A, Mutukumira AN, Weber JL, Brough L, Coad J. Sweet potato-based complementary food for infants in low-income countries. Food Nutr Bull. 2012;33(1):3-10.

74. R. Alonso, A. Aguirre, F. Marzo. Effects of extrusion and traditional processing methods in antinutrients and in vitro digestibility of protein and starch in faba and kidney beans. Food chemistry.2000;68(2):159-165. Doi:10.1016/S0308-8146(99)001697

75. Satinder Kaur, Savita Sharma, Baljit Singh, B. N. Dar. Effect of extrusion variables (temperature, moisture) on the antinutrient components of cereal brans. Journal of Food Science and Technology.2015;52(3):1670-1676. Doi:10.1007/s13197-013-11184

76. P. Houssou. Development of rice parboiling in Benin, African savannahs: changing spaces, actors facing new challenges. Proceedings of the colloquium, Garoua, Cameroon. Cirad-Prasac.2003.

77. Mahesh S, Pavithra GJ, Parvathi MS, Rajashekara Reddy, Shankar A G. Effect of processing on phytic acidity and nutrient availability in food grains. International Journal of Agricultural Sciences.2015;5(5):771-777.

78. Mathew K. Bolade. Individualistic impact of unit operations of production, at household level, on some antinutritional factors in selected cowpea-based food products. Food Sci Nutr. 2016; 4(3): 441455. Doi: $10.1002 /$ fsn3.306

79.E.A. Udensi , F.C. Ekwu, J.N. Isinguzo. Antinutrient factors of vegetable cowpea (Sesquipedalis) seeds during thermal processing. Pakistan Journal of Nutrition.2007;6(2):194-197.Doi: 10.3923/ pjn.2007.194.197

80. J.M. Awika and K.G. Duodu. Bioactive polyphenols and peptides in cowpea (Vigna unguiculata) and their health promoting properties: A review. Journal of Functional Foods.2016;

81. Kaur S, Sharma S, Dar BN, Singh B. Optimization of process for reducing antinutritional factors in edible cereal brans. Food Sci Technol Int. 2012;18(5):445-54. Doi: 10.1177/1082013211428236 